\title{
THE EFFECTS OF LEARNING MEDIA AND VOCABULARY MASTERY TOWARDS READING ENGLISH TEXT SKILL
}

\author{
Yusuf Hekmatiar $^{1}$, Chotibul Umam \\ Universitas Banten Jaya \\ Serang, Indonesia \\ yusufhekmatiar@unbaja.ac.id \\ chotibulumam@unbaja.ac.id
}

\begin{abstract}
The purpose of this researce is to find out the effect of learning media towards reading English text skill, the effect of vocabulary mastery towards reading English text skill, the interaction effects of learning media and vocabulary mastery towards reading English text skill. The research methodology that is used in this research is experiment by giving different types of treatment to two student learning groups. The sample is 44 students, consist of 22 experimental class students and 22 control class students, with the sampling technique in this study being intact class based on Factorial Group Design. Data analysis used descriptive statistical method, normality test, homogeneity test, and two-way ANOVA. This research was conducted in the even semester of 2019/2020 academic year, October - November 2019. The results of the study showed: 1) There is significant effect of learning media towards reading English text skill, It is proved by the value of Sig. $=0,000<0,05$ and $\left.\mathrm{F}_{0}=64,015.2\right)$ There is significant effect of vocabulary mastery towards reading English text skill, It is proved by the value of $\mathrm{Sig} .=0,000<0,05$ and $\mathrm{F}_{0}=6,682$. 3) There are no significant interaction effects of learning media and vocabulary mastery towards reading English text skill, It is proved by the value of Sig. $=0,183>0,05$ and $\mathrm{F}_{0}=1,833$.
\end{abstract}

\section{Key Words: Learning Media, Vocabulary Mastery, Reading Skill}

\section{Introduction}

Language is a system of speech sounds that are arbitrary or arbitrary. Language is used to symbolize human thoughts and feelings in order to convey meaning to others. Language is an important element in communication. This shows that without language, communication cannot be done well and social interactions never occur.

Without language someone is not able to express and convey a message to others. In communicating there are various varied objectives in it, such as to get information, to establish kinship, or to conduct trade transactions as in the current era.

People use language as a vital means of communication in life. Language is human property. Language is one of the main distinguishing features of humans from other living things in the world (Tarigan, 2011: 8). Thus, language has an important role in communicating activities, both oral and written. 
With language, one can express desires, explain ideas, express thoughts and ideas to others. Furthermore, English learning in schools aims to make students skilled in language which includes listening, speaking, reading and writing skills.

Reading skills must be possessed by everyone, because through reading someone gets a new vocabulary that helps enrich vocabulary so that they are more skilled. Constraints in reading are difficult to understand the meaning of words; words in English are difficult to understand. The possible cause is that they only master a limited vocabulary, and they also don't have effective reading techniques or strategies. One word sometimes has many meanings. Though vocabulary determines how skilled someone is in speaking. As expressed by Tarigan (2008: 2), the quality of one's language skills clearly depends on the quantity and quality of the vocabulary he has. The richer the vocabulary we have, the more likely we are to be skilled in language.

Various kinds of learning media used by teachers. Including power point media. Media Power point is an application program designed to display multimedia programs. Multimedia has been widely used by teachers or educators to deliver teaching material to students. It is believed that the use of multimedia in a learning activity can improve the results of learning activities.
Learning media is basically one component of the learning system. Without media, communication will not occur and the learning process as a communication process will not be able to take place optimally. The use of learning media can help children to provide meaningful experiences for students and make it easier for students to understand something abstract to be more concrete. One medium that can be applied to transfer material is ICT (Integrated Computer Technology) by utilizing Microsoft power point as educational software in learning.

Teaching in schools in general are still many that use conventional media or better known as traditional media. As teachers, we should try to improve the quality of teaching by using more modern media, such as using media that uses technology such as a set of laptops, projectors, and LCDs to increase motivation to learn students' reading skills and obtain satisfying learning outcomes to be more creative and competitive in community life.

In addition, vocabulary also has an important role because it appears in every language skill. Understanding vocabulary is very important in every language learning. Mastery of vocabulary is also needed to communicate with the community as stated by Keraf (1991: 21-24), those who master many ideas, or in other words those with a broad vocabulary, can easily and smoothly communicate with others. Those whose vocabulary is broad will have a high ability to choose exactly which words are the 
most harmonious to have their intentions or ideas.

Based on the description above, the author is interested in researching the effects of learning media and vocabulary mastery towards reading English text skill. (experiment in private MA in Serang, Banten).

\section{Research Methodology}

This research uses the experimental method, namely by giving different types of treatment to two student learning groups. One group was used as the experimental group, which was given the treatment of learning to read English with power point media, while the other group as a control group with the treatment of learning with conventional media.

\section{Research Findings and Discussion}

After fulfilling the assumptions that the data is in a normal distribution and homogeneous variance, it can be continued by testing the research hypothesis. The research hypothesis uses analysis of variance (ANOVA). In testing this hypothesis, SPSS 20 for Windows is used.

The following are the summary results of the data analysis: 
Table 4.4

ANOVA Result

Reading English Text Skill Data

Tests of Between-Subjects Effects

\begin{tabular}{|c|c|c|c|c|c|}
\hline Source & $\begin{array}{l}\text { Type III Sum of } \\
\text { Squares }\end{array}$ & df & Mean Square & $\mathrm{F}$ & Sig. \\
\hline Corrected Model & $2719.886^{\mathrm{a}}$ & 3 & 906.629 & 24.177 & .000 \\
\hline Intercept & 217705.114 & 1 & 217705.114 & 5805.470 & .000 \\
\hline Media & 2400.568 & 1 & 2400.568 & 64.015 & .000 \\
\hline Kosakata & 250.568 & 1 & 250.568 & 6.682 & .013 \\
\hline Media * Kosakata & 68.750 & 1 & 68.750 & 1.833 & .183 \\
\hline Error & 1500.000 & 40 & 37.500 & & \\
\hline Total & 221925.000 & 44 & & & \\
\hline Corrected Total & 4219.886 & 43 & & & \\
\hline
\end{tabular}

a. R Squared $=.645($ Adjusted $R$ Squared $=.618)$

Based on the results of calculations in table 4.2

it can be explained that:

\section{Hypothesis Testing 1}

This hypothesis is to test whether or not the influence of instructional media on the ability to read English texts. In other words, knowing how much learning media affects reading English texts with the statistical hypothesis as follows:
$\mathrm{H}_{\mathrm{o}} \quad$ : There is no significant effect of learning media towards reading English texts skill.

$\mathrm{H}_{1}$ : There is a significant effect of learning media towards reading English texts skill. 
If the value Sig. is > 0.05; then $\mathrm{H}_{0}$ is accepted and $\mathrm{H}_{1}$ is rejected.

If the value $\mathrm{Sig}$. is > 0.05 ; then $\mathrm{H}_{1}$ is accepted dan $\mathrm{H}_{\mathrm{o}}$ is rejected.

From the testing with SPSS 20 above, the value of Sig. $=0,000<0,05$ and $F_{0}=$ 64,015. Thus, it can be concluded that there is a significant effect of learning media towards reading English texts skill.

\section{Hypothesis Testing 2}

This hypothesis is to test whether there is an effect of vocabulary mastery on the ability to read English texts. In other words, knowing how much vocabulary mastery affects the reading English texts skill with the statistical hypothesis as follows:

$\mathrm{H}_{\mathrm{o}} \quad$ : There is no significant effect of vocabulary mastery towards reading English texts skill.

$\mathrm{H}_{1} \quad$ : There is a significant effect of vocabulary mastery towards reading English texts skill.

If the value Sig. is $>0.05$; then $\mathrm{H}_{0}$ is accepted and $\mathrm{H}_{1}$ is rejected.

If the value Sig. is $>0.05$; then $\mathrm{H}_{1}$ is accepted dan $\mathrm{H}_{\mathrm{o}}$ is rejected.
From the testing with SPSS 20 above, the value of Sig. $=0,013<0,05$ and $\mathrm{F}_{0}=$ 6,682 . Thus, it can be concluded that there is a significant effect of vocabulary mastery towards reading English texts skill.

\section{Hypothesis Testing 3}

This hypothesis is to test whether there are interaction effects of learning media and vocabulary mastery on reading English texts skill. In other words, knowing how much learning media and vocabulary mastery affects the reading English texts skill with the statistical hypothesis as follows:

$\mathrm{H}_{\mathrm{o}}$ : There are no significant interaction effects of learning media and vocabulary mastery on reading English texts skill.

$\mathrm{H}_{1}$ : There are significant interaction effects of learning media and vocabulary mastery on reading English texts skill.

If the value Sig. is > 0.05 ; then $\mathrm{H}_{0}$ is accepted and $\mathrm{H}_{1}$ is rejected.

If the value Sig. is > 0.05 ; then $\mathrm{H}_{1}$ is accepted dan $\mathrm{H}_{\mathrm{o}}$ is rejected.

From the testing with SPSS 20 above, the value of Sig. $=0,183>0,05$ and $F_{0}=$ 1,833. Thus, it can be concluded that 
There are no significant interaction effects of learning media and vocabulary mastery on reading English texts skill.

\section{Conclusions and Suggestions}

Based on the results of the research hypothesis testing and data processing analysis chapter IV, it can be summarized as follows:

There is a significant effect of learning media towards reading English texts skill. It is proved by the value of Sig. $=0,000<0,05$ and $F_{0}=$ 64,015 , the average score of the ability to read English texts with powerpoint media was 81.36 higher than the results of learning English with conventional media, namely 74.09 . This shows that the ability to read English texts will increase if students are taught with powerpoint media.

There is a significant effect of vocabulary mastery towards reading English texts skill. It is proved by the value of Sig. $=0,013<0,05$ dan $F_{0}$ $=6,682$, he average score of the ability to read English texts with mastery of high learning vocabulary is 64.09 higher than the ability to read English texts with mastery of low learning vocabulary which only reaches 61.82 . This shows that the ability to read English texts is better if students have high vocabulary mastery.

There are no significant interaction effects of learning media and vocabulary mastery on reading English texts skill. It is proved by the value of Sig. $=0,183>0,05$, and $F_{0}=1,833$.
Based on the conclusions and implications of the research, then some related suggestions that can be conveyed by the authors in this research are:

1. Powerpoint media can be applied in various learning media, therefore English teachers should increase the theoretical knowledge of powerpoint media strategies and practice to get used to using fun and varied powerpoint media.

2. Cooperation between English teachers is needed in optimizing the ability to learn English. This collaboration is a means of exchanging teaching experiences according to strategies and learning media by each teacher.

3. Teachers should develop and improve their theories mastery related to English subjects.

4. Teacher always trains the students to increase their English vocabulary. Encourage students to always gain mastery of their vocabulary through listening activities such as news, films and other media, practice speaking, writing and reading.

5. Teachers always encourage students to love reading. Reading activities have been implemented in several schools in West Java through the Literacy Movement program. The teacher can promote the English reading program into the Literacy Movement program in the school by entering English text into the activity so that students are more likely to love reading English texts. 


\section{References}

Abdullah, S. I. (2016). Buku saku percepatan penyusunan tesis. Tangerang: Pustaka Mandiri.

Akhadiah, S (1991). Pembinaan kemampuan menulis bahasa Indonesia. Jakarta: Gelora Aksara Pramata.

Al-Kufashi. (2008). Kajian Wacana. Yogyakarta : Tiara Wacana.

Alwi, H. (2009). Tata Bahasa Baku Bahasa Indonesia. Jakarta: Penerbit Balai Pustaka.

Ardiana, L.I. (2002). Semantik bahasa Indonesia. Pelatihan terintegrasi berbasis kompetensi guru pelajaran bahasa Indonesia. Direktorat Sekolah Lanjutan Tingkat Pertama, Direktorat Jendral Pendidikan Dasar dan Menengah Departemen Pendidikan Nasional.

Arikunto, S. (2013). Prosedur penelitian. Jakarta: Rineka Cipta.

Brown, H. D. (2001). Teaching by principles. New York: Addison Wesley Longman.

Carter, S.D. (2008). A reader's Guide to Contemporary Literary Theory. Liverpool: Harvester Press.

Depdiknas. (2008). Kamus besar bahasa Indonesia. Jakarta: Gramedia Pustaka Utama.

Dunnette. (1976). Keterampilan Mengaktifkan Siswa. Kencana Prenada Media Group : Jakarta

Farris. H. (2005). Active Learning, 101 Cara Belajar Siswa Aktif. Bandung : Nusamedia.
Gagne, R. M. (2009). The Conditional of Learning, Florida : Holt, Rienhart and Winstone.

Halim, A. (2004). Pembinaan Bahasa Nasional. Jakarta Pusat Pembinaan Pengembangan Bahasa Departemen Pendidikan dan Kebudayaan.

Halliday, R. (2010). Rancangan Pengajaran Bahasa dan Sastra Indonesia. Bandung: Angkasa.

Harmer, J. (1991). The practice of English language teaching: Third Edition. New York: Longman Publishing.

Harmer, J. (2001). The practice of English language teaching: Fourth Edition. Essex: Longman Pearson Education Limited.

Hernowo. (2002). Memupuk Bakat dan Kreativitas Siswa Sekolah Menengah. Jakarta: Gramedia.

Keraf, G. (1991). Tata bahasa rujukan bahasa Indonesia. Jakarta: Gramedia Widiasatya.

Nasucha, Y., Rohmadi, M. \& Wahyudi, A. B. (2009). Bahasa Indonesia untuk penulisan karya tulis ilmiah. Yogyakarta: Media Perkasa.

Nurgiyantoro, B. (2001). Penilaian dalam pembelajaran bahasa dan sastra. Bandung: P.T. Kiblat Buku Utama.

Nurgiantoro, B. (2001). Penilaian Pembelajaran Bahasa Berbasis Kompetensi. Yogyakarta: BPFE.

Read, J. (2000). Assessing Vocabulary. Cambridge: Cambridge University Press.

Safari. 2008. Analisis Butir Soal Tes dan Non Tes. Jakarta: CV Purnama. 
Sardiman, A.M. (2012). Interaksi dan Motivasi Belajar Mengajar. Jakarta: PT Raja Grafindo Persada.

Scovel, T. (1998). "A Critical review of the critical period research". Annual review of applied linguistics. 13/1: 1-18.

Seyler, D.U. (2004). The Reading Context: Developing College Reading Skill. Newyork: Longman.

Sudjana, N. (2006). Metode Statistika, Bandung: Tarsito.

Sudjana, N. (2004). Dasar-Dasar Proses Belajar Mengajar. Bandung: Sinar Baru Algensido Offset.

Sugihartono, Dkk. (2007). Psikologi Pendidikan. Yogyakarta. UNY Press.

Sugiyono, (2016). Metode penelitian kuantitatif kualitatif, dan $r \& d$. Bandung: Alfabeta.

Suryanto. (2009). Sosiologi Teks Pengantar dan Terapan, Jakarta: Prenada Media.

Syaiful, B.D. \& Zain, A. (2011). Psikologi Belajar. Jakarta: Rineka Cipta.

Syaiful, S. (2012). Supervisi Pembelajaran dalam Proses Pendidikan. Bandung: Alfabeta.

Tavakoli, H. (2012). A dictionary of research methodology and statistics in applied linguistic. Tehran: Rahmana Press.

Tarigan, H.G. (2003). Membaca Sebagai Suatu Keterampilan Berbahasa. Bandung: Angkasa.

Tarigan, H. G. (2008). Berbicara sebagai suatu keterampilan berbahasa. Bandung: Angkasa.
Tarigan, H. G. (2008). Membaca. Bandung: Angkasa.

Thornbury, S. (2002). How to teach vocabulary. London: Pearson Longman.

Tsui, A., \& Tollefson, J. (2007). Language Policy, Culture, and Identify in Asian Contexts. Lawrence Erlbaum.

Uyanto, S. S. (2009). Pedoman analisis data dengan SPSS. Yogyakarta: Graha Ilmu. 
